\title{
Analisis Penerapan Biaya Kualitas untuk Meningkatkan Profitabilitas pada PT. Veloxa Viggo Inti Teknologi di Surabaya
}

\author{
*Lia Anatasya, Arief Rahman, Mahsina \\ Prodi Manajemen Fakultas Ekonomi dan Bisnis \\ Universitas Bhayangkara Surabaya, Indonesia
}

DOI: $10.46821 /$ ekobis.v2i1.211

\begin{abstract}
ABSTRAK
PT. Veloxa Viggo Inti Teknologi adalah salah satu perusahaan yang bergerak dalam bidang teknologi. Berdasarkan observasi pada tahun 2020 terjadi adanya perbaikan kualitas akan produk dan kualitas PT Veloxa Viggo Inti Teknologi. Tujuannya untuk menganalisis penerapan biaya kualitas dalam rangka meningkatkan profitabilitas. Jenis penelitian ini adalah metode kualitatif deskriptif dengan data yang digunakan adalah laporan keuangan. Untuk mengetahui biaya apa saja yang telah dikeluarkan oleh perusahaan dengan menentukan tingkat kualitas produknya yang meliputi kinerja, kehandalan, kesesuaian dengan spesifikasi, pelayanan dan persepsi kualitas. Suatu produk dapat dikatakan memiliki kualitas yang baik jika terdapat tingkatan kualitas produk tersebut. Hal ini dapat dibuktikan pada tahun 2019 total biaya kualitas sebesar 74,3 juta dan tingkat profitabilitas sebesar $35.26 \%$, sedangkan pada tahun 2020 total biaya kualitas sebesar 83.5 juta dan tingkat profitabilitas $89.92 \%$. Saran yang dapat disampaikan peneliti untuk PT. Veloxa Viggo Inti Teknologi adalah perusahaan mengevaluasi kembali biaya kualitas terhadap profitabilitas pada setiap penurunan kualitas produk.
\end{abstract}

Kata Kunci: Biaya Kualitas, Profitabilitas

\begin{abstract}
PT. Veloxa Viggo Inti Teknologi is a technology company. Based on observations in 2020 there was an improvement in product quality and the quality of PT Veloxa Viggo Inti Teknologi. The aim is to analyze the application of quality costs in order to increase profitability. This type of research is a descriptive qualitative method with the data used are financial statements. To find out what costs have been incurred by the company by determining the level of product quality which includes performance, reliability, conformance to specifications, service and perceived quality. A product can be said to have good quality if there is a level of product quality. This can be proven in 2019 the total cost of quality was 74.3 million and a profitability rate of $35.26 \%$, while in 2020 the total cost of quality was 83.5 million and a profitability rate of $89.92 \%$. Suggestions that can be submitted by researchers for PT. Veloxa Viggo Inti Teknologi is the company reevaluates the cost of quality against profitability against any decline in product quality.
\end{abstract}

Keywords: Cost Quality, Profitability 


\section{PENDAHULUAN}

PT. Veloxa Viggo Inti Teknologi adalah salah satu perusahaan yang bergerak dalam bidang teknologi. Kegiatan perusahaan tersebut meliputi: Instalasi dan Konstruksi jaringan data kabel/nirkabel, Instalasi perangkat keamanan (CCTV \& Akses door), Instalasi Komunikasi, Pengadaan Perangkat Komputer dan Komunikasi, Pengembangan Perangkat Lunak untuk Sistem Utama ataupun Pendukung Perusahaan, Maintenance dalam bidang teknologi informasi dan engineering , Instalasi dan Konstruksi Kelistrikan.

PT. Veloxa Viggo Inti Teknologi memiliki proses bisnis mitra kerja (yaitu mitra bisnis yang menyeleksi pelanggan untuk memasang CCTV, Pemasangan Kabel, dan lain-lain), kemudian klien akan menentukan posisi pemasangan, setelah itu mitra kerja akan menyediakan pengadaan barang yang akan dilakukan pemasangan, kemudian karyawan dari PT. Veloxa Viggo Inti Teknologi akan melakukan pemasangan sesuai kebutuhan klien.

PT. Veloxa Viggo Inti Teknologi mengeluarkan biaya pelatihan karyawan, biaya pengawasan, biaya pengerjaan ulang (rework) dan biaya perbaikan. Biaya pelatihan karyawan termasuk dalam biaya pencegahan, biaya pengawasan termasuk biaya penilaian, biaya pengerjaan ulang termasuk dalam biaya kegagalan internal dan biaya perbaikan termasuk biaya kegagalan eksternal. Biaya kualitas ini dapat dilakukan dengan cara meminimalisasi adanya rework atas layanan jasa yang nantinya akan mengurangi pemborosan sehingga biaya kegagalannya pun akan menurun.

PT. Veloxa Viggo Inti Teknologi melakukan pelatihan karyawan yang dilakukan setiap tahun yang termasuk dalam biaya kualitas. Biaya tersebut digunakan untuk meningkatkan keahlian karyawan dan untuk meningkatkan penjualan layanan jasa. Pendapat jasa perusahaan mengalami fluktuasi tiap tahunnya. Perbandingan pendapatan jasa yang terjadi pada dari tahun 2019 sampai dengan tahun 2020.

Berdasarkan observasi, terjadi adanya perbaikan kualitas akan produk dan kualitas PT Veloxa Viggo Inti Teknologi. Perbandingan anggaran biaya menyimpang dari konsep biaya kualitas yang ada sehingga mengalami over budget. Diketahui anggaran dana yang digunakan untuk melakukan perbaikan kualitas adalah Rp. 74.350 .000 juta pada tahun 2019 sedangkan pada tahun 2020 adalah Rp. 83.568.000. Angka tersebut dinilai cukup besar dibandingkan anggaran tahun sebelumnya.

Berdasarkan hasil analisa dua periode laporan keuangan terdapat perbedaan terkait anggaran dana yang digunakan untuk perbaikan kualitas produk perusahaan. Hal ini menyebabkan, laba atau profit PT. Veloxa Viggo Inti Teknologi tidak dapat maksimal. Menghasilkan produk yang berkualitas sangat penting bagi keberlangsungan perusahaan.

Oleh sebab itu perlu dilakukan analisis biaya kualitas agar dapat memperhitungkan seberapa besar biaya kualitas dan juga dapat dijadikan dasar pengambilan keputusan oleh manajer.

Atas dasar uraian singkat permasalahan diatas, penulis ingin menganalisis penerapan biaya kualitas pada PT. Veloxa Viggo Inti Teknologi. Tujuannya untuk meningkatkan profit pada PT. Veloxa Viggo Inti Teknologi. 


\section{TINJAUAN PUSTAKA \\ Pengertian Biaya Kualitas}

Menurut Hansen dan Mowen (2009) biaya kualitas (cost of quality) yaitu biayabiaya yang timbul karena mungkin atau telah terdapat produk yang kualitasnya buruk. Blocher dkk., (2000) berpendapat bahwa biaya kualitas adalah biaya dari aktivitas yang berkaitan dengan pencegahan, pengidentifikasian, perbaikan dan pembetulan produk yang berkualitas rendah dan dengan opportunity cost dari hilangnya waktu produksi dan penjualan sebagai akibat rendahnya kualitas.

\section{Klasifikasi Biaya Kualitas}

Aktivitas-aktivitas yang dilakukan dalam sutu perusahaan tidaklah sama persis dengan aktivitas-aktivitas yang dilakukan diperusahaan lain. Sehingga perlakuan biaya kualitas yang diterapkan harus disesuaikan dengan kondisi perusahaan masing-masing. Menurut Hansen dan Mowen (2009) biaya kualitas dibagi menjadi 4 kategori yaitu:

a. Biaya pencegahan merupakan biaya yang terjadi untuk mencegah kualitas yang buruk pada produk atau jasa yang dihasilkan.

b. Biaya penilaian merupakan biaya yang terjadi untuk menentukan apakah produk dan jasa telah sesuai dengan persyaratan atau kebutuhan pelanggan.

c. Biaya kegagalan internal terjadi karena produk atau jasa yang dihasilkan tidak sesuai dengan spesifikasi atau kebutuhan pelanggan.

d. Biaya kegagalan eksternal terjadi karena produk dan jasa yang dihasilkan gagal memenuhi persyaratan atau tidak memuaskan kebutuhan pelanggan setelah produk disampaikan kepada pelanggan.

\section{Pengertian Profitabilitas}

Menurut Harahap (2016) "Profitabilitas adalah kemampuan perusahaan menghasilkan laba yang digambarkan oleh Return on Investment (ROI), ROI dapat digambarkan lebih rinci oleh Ratio Profit Margin dan Capital Turn Over.

\section{Ukuran Profitabilitas}

Menurut Sutrisno (2014) rasio profitabilitas dapat diukur sebagai berikut:

1. Margin Laba kotor (gross profit margin). Angka ini menunjukkan presentase dari setiap hasil sisa penjualan sesudah membayar harga pokok penjualan. Semakin besar rasio ini semakin baik karena semakin rendah harga pokok barang yang dijual.

$\cdot($ gross profit margin $)=\frac{\text { Pendapatan }- \text { Harga Pokok Penjualan }}{\text { Penjualan }}$

2. Profit on Sales dipergunakan untuk menilai profitabilitas, sekaligus kemampuan manajemen perusahaan menekan biaya operasional.

$$
\text { Profit on Sales }=\frac{\text { Laba sesudah pajak }}{\text { Penjualan Bersih }} \times 100 \%
$$

3. Return on Equity. Pada rasio ini menunjukkan berapa persen diperoleh laba bersih apabila diukur dari modal pemilik. Semakin besar maka semakin baik.

$$
\text { Return on Equity }=\frac{\text { Laba Bersih }}{\text { Ekuitas pemegang saham }}
$$


4. Return on Total Assets. Pada rasio ini menunjukkan berapa besar laba bersih diperoleh perusahaan apabila diukur dari nilai aktiva

$$
\text { Return on Total Assets }=\frac{\text { Laba Bersih }}{\text { Rata-rata total aset }} \text {. }
$$

\section{Hubungan Analisis Biaya Kualitas Dengan Laba (Profit)}

Menurut Lin dkk., (2002) "Sebagian besar perusahaan mengeluarkan biaya kualitas sebesar 20-25\% dari penjualannya, dan sekitar $40 \%$ biaya yang terjadi dalam proses bisnis terjadi akibat dari kualitas yang buruk. Dengan kata lain, perusahaan yang menghasilkan barang dan jasa yang berkualitas memperoleh kelebihan dalam hal penjualan (sales gain) dan dalam hal perolehan profit (high profit)."

\section{Pengaruh Biaya Kualitas terhadap Profitabilitas}

Apabila biaya pencegahan dan penilaian meningkat, maka biaya kegagalan internal dan eksternal akan menurun. Hal ini akan berpengaruh terhadap kualitas produk yang dihasilkan meningkat, karena produk akan sesuai dengan spesifikasi desain awal tanpa memilki suatu kecacatan baik sebelum maupun setelah produk tersebut dikirim ke konsumen.

\section{Model Analisis}

Model analisis penerapan biaya kualitas pada PT. Veloxa Viggo Inti Teknologi di Surabaya yang disusun oleh peneliti dapat dilihat pada Gambar 2.

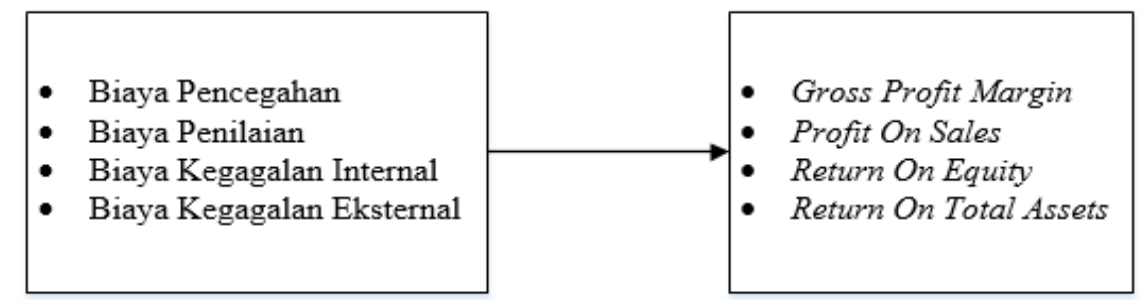

Gambar 1. Kerangka Konseptual

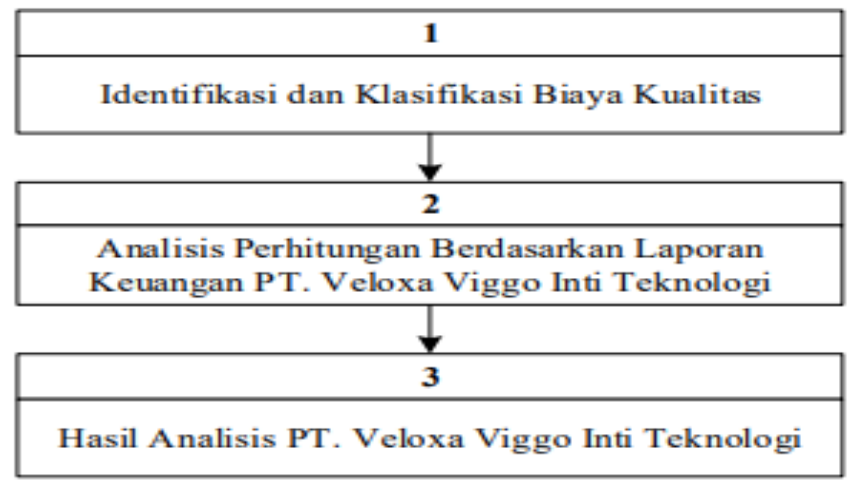

Gambar 2. Model Analisa 


\section{METODE PENELITIAN \\ Pendekatan Penelitian}

Jenis penelitian yang digunakan dalam penelitian ini adalah metode kualitatif deskriptif dengan pendekatan studi kasus. Penelitian kualitatif adalah suatu proses penelitian yang berdasarkan pada metodologi yang menyelidiki suatu fenomena sosial dan masalah manusia Noor (2012). Penelitian deskriptif adalah penelitian yang menggambarkan suatu gejala, peristiwa, kejadian dengan berpusat pada masalah yang terjadi saat penelitian berlangsung. Hardiansyah (2012) pendekatan studi kasus adalah suatu model penelitian kualitatif yang terperinci tentang individu atau suatu unit sosial tertentu selama kurun waktu tertentu.

\section{Jenis Data}

Jenis data untuk penelitian ini menggunakan 2 jenis data yaitu sebagi berikut:

a. Data primer, yaitu data yang diperoleh langsung dari observasi dan wawancara langsung pada pihak yang berwenang Nur dan Bambang (2008).

b. Data sekunder, yaitu data yang diperoleh dokumen-dokumen dan bahan tertulis, baik yang berasal dari dalam perusahaan maupun dari luar dalam perusahaan yang berhubungan dengan masalah yang akaan dibahas Sugiono (2017).

\section{Sumber Data}

Sumber data yang digunakan peneliti yaitu diperoleh langsung dari PT. Veloxa Viggo Inti Teknologi dengan dibantu pihak manajemen dan karyawan yang ada di dalam perusahaan. Skripsi dari peneliti sebelumnya sebagai peneliti terdahulu dan buku-buku yang digunakan sebagai pedoman.

\section{Lokasi Penelitian}

Penelitian ini dilaksanakan di PT. Veloxa Viggo Inti Teknologi yang beralamat di Jl. Baliwerti No.6 RT. 001 RW. 010 Alun-Alun Contongan Bubutan Kota Surabaya 60177. Sedangkan waktu penelitian ini dilaksanakan dari bulan Desember 2020 sampai Maret 2021.

\section{Teknik Pengumpulan Data}

Adapun teknik pengumpulan data dalam penelitian ini adalah:

a. Interview (wawancara). Peneliti melakukan wawancara mendalam kepada informan agar lebih banyak memperoleh informasi Sugiono (2017).

b. Observasi (pengamatan). Dalam penelitian ini akan dilakukan observasi terhadap sistem akuntansi pada pencatatan biaya kualitas perusahaan yang dijalankan Sutrisno (2016).

\section{Pengujian Data}

Menurut Chalid dan Abu (2006) setelah seluruh data terkumpul maka diperlukan adanya pengujian data dengan tahapaan-tahapan sebagai berikut:

1. Editing. Penulis menggunakan teknik ini untuk memeriksa kelengkapan datadata yang sudah penulis dapatkan di PT. Veloxa Viggo Inti Teknologi dan akan digunakan sebagai sumber- sumber studi dokumentasi.

2. Organizing. Teknik ini digunakan penulis untuk menyusun dokumen atau informasi yang telah diperoleh di PT. Veloxa Viggo Inti Teknologi supaya bisa menjawab semua pertanyaan di rumusan masalah. 
3. Analyzing. Teknik ini dilakukan penulis untuk menganalisis antara data yang diperoleh di PT. Veloxa Viggo Inti Teknologi dengan teori yang sudah menjadi acuan untuk menganalisis.

\section{Teknik Analisis}

Sugiono (2010) untuk dapat menganilisis data yang ada supaya dapat ditarik suatu kesimpulan, maka langkah-langkah yang dilakukan peneliti adalah sebagai berikut:

a. Identifikasi dan klasifikasi biaya kualitas, menghasilkan data-data yang berhubungan dengan biaya kualitas dari objek atau sumber yang sedang diteliti.

b. Analisis perhitungan berdasarkan laporan keuangan meliputi pelaporan biaya kualitas, laporan laba rugi, laporan tingkat EAT (Earning After Tax), tingkat profitabilitas dan perbandingan total biaya kualitas dengan tingkat profitabilitas PT. Veloxa Viggo Inti Teknologi.

c. Hasil analisis disusun berdasarkan landasan fakta-fakta yang bersifat khusus (induktif) yang akan menghasilkan sebuah kesimpulan yang dapat digunakan untuk memecahkan masalah dan dapat memberikan solusi pada PT. Veloxa Viggo Inti Teknologi sebagai objek penelitian.

\section{HASIL ANALISIS DAN PEMBAHASAN}

\section{Laporan Laba/Rugi}

Data-data akuntansi dalam penelitian ini tersedia juga pada Laporan Laba/Rugi Tahun 2019 dan 2020 PT. Veloxa Viggo Inti Teknologi, dapat dilihat pada Tabel 1.

Tabel 4.1

Laporan Laba/Rugi Perusahaan Tahun 2019-2020

\begin{tabular}{|c|c|c|}
\hline & 2019 & 2020 \\
\hline Penjualan & Rp. 719.246.890 & Rp. 290.786 .567 \\
\hline Harga Pokok Penjualan & -Rp. 319.454.120 & -Rp. 83.454.120 \\
\hline Laba Kotor & Rp. 399.792.770 & Rp. 207.332 .447 \\
\hline \multicolumn{3}{|l|}{ Beban Operasi } \\
\hline Biaya Karyawan Tetap \& Uang Muka & Rp. 84.897.689 & Rp. 36.789 .789 \\
\hline Biaya Pemasaran & Rp. 32.647 .900 & Rp. 16.641 .786 \\
\hline Biaya Penyusutan \& Amortisasi & Rp. 30.125 .000 & Rp. 17.889 .000 \\
\hline Biaya Utility, Adm. Sewa \& Lainnya & Rp. 5.600 .000 & Rp. 3.000 .000 \\
\hline Biaya Kualitas & Rp. 74.350 .000 & Rp. 83.568.000 \\
\hline Jumlah Beban Operasi & Rp. 263.266.589 & Rp. 173.577 .465 \\
\hline Laba Operasi & Rp. 136.526 .181 & Rp. 33.754.982 \\
\hline \multicolumn{3}{|l|}{ Pendapatan Lain-lain } \\
\hline Pendapatan Bunga Deposito & Rp. 40.897 & Rp. 25.800 \\
\hline Pendapatan Lainnya & Rp. 120.602 .791 & Rp. 230.987.675 \\
\hline Jumlah Pendapatan Lain-lain & Rp. 120.643 .688 & Rp. 231.013 .475 \\
\hline \multicolumn{3}{|l|}{ Beban Lain-lain } \\
\hline Biaya Bunga Pinjaman Lainnya & Rp. 897 & Rp. 789 \\
\hline $\begin{array}{l}\text { Biaya Administrasi Bank \& buku } \\
\text { Cek/Giro }\end{array}$ & Cek/Giro & Rp. 635.000 \\
\hline Biaya Pajak Jasa Giro/Tabungan & Rp. 1.897 & Rp. 1.678 \\
\hline Jumlah Beban Lain-lain & Rp. 992.294 & Rp. 637.467 \\
\hline Jumlah Pendapatan dan Beban Lain=lain & Rp. 119.651.394 & Rp. 230.376 .008 \\
\hline Laba/Rugi Bersih (Before Tax) & Rp. 256.177 .575 & Rp. 264.130 .990 \\
\hline Pajak $1 \%$ & -Rp. 2.561 .775 & -Rp. 2.641.309 \\
\hline Laba/Rugi Bersih (After Tax) & Rp. 253.615.800 & Rp. 261.489.681 \\
\hline
\end{tabular}

Sumber: Data Diolah (2020) 


\section{Neraca}

Data-data akuntansi yang lebih rinci diperlukan dalam penelitian ini tersedia juga pada Laporan Keuangan Neraca PT. Veloxa Viggo Inti Teknologi. Laporan Neraca Perusahaan tahun 2019 dan 2020 dapat dilihat pada Tabel 2.

\section{Persentase Biaya Kualitas}

Persentase biaya kualitas perusahaan pada tahun 2019-2020 dalam penelitian ini dapat dilihat pada Tabel 3.

Tabel 2

Laporan Neraca Perusahaan Tahun 2019-2020

\begin{tabular}{|c|c|c|}
\hline & 2019 & 2020 \\
\hline \multicolumn{3}{|l|}{ Aktiva Lancar } \\
\hline Kas & Rp. 258.900 .450 & Rp. 246.750 .000 \\
\hline Bank & Rp. 8.750 .000 & Rp. 12.600 .500 \\
\hline Piutang Dagang & Rp. 16.897 .000 & Rp. 21.987 .650 \\
\hline Persediaan Barang Dagang & Rp. 114.500 .000 & Rp. 119.850 .000 \\
\hline Total Aktiva Lancar & Rp. 339.047 .450 & Rp. 401.188 .150 \\
\hline \multicolumn{3}{|l|}{ Aktiva Tetap } \\
\hline Bangunan & Rp. 350.000 .000 & Rp. 350.000 .000 \\
\hline Inventaris & Rp. 9.000 .000 & Rp. 9.000 .000 \\
\hline Kendaraan & Rp. 80.000 .000 & Rp. 80.000 .000 \\
\hline Perlatan & Rp. 1.100 .000 & Rp. 1.100 .000 \\
\hline \multicolumn{3}{|l|}{ Akumulasi Penyusutan } \\
\hline Ak. Py. Bangunan & -Rp. 155.700 .650 & -Rp. 189.500 .790 \\
\hline Ak. Py. Inventaris & -Rp. 4.600 .000 & -Rp. 6.100 .000 \\
\hline Ak. Py. Kendaraan & -Rp. 32.000 .000 & -Rp. 34.000 .000 \\
\hline Ak. Py. Peralatan & Rp. 550.000 & Rp. 600.000 \\
\hline Total Aktiva Tetap & Rp. 248.349 .350 & Rp. 211.099 .210 \\
\hline Total Aktiva & Rp. 647.396 .800 & Rp. 612.287 .360 \\
\hline \multicolumn{3}{|l|}{ Kewajiban } \\
\hline \multicolumn{3}{|l|}{ Kewajiban Lancar } \\
\hline Hutang Dagang & Rp. 6.347 .895 & Rp. 8.950 .000 \\
\hline \multicolumn{3}{|l|}{ Kewajiban Jangka Panjang } \\
\hline Total Kewajiban & Rp. 6.347 .895 & Rp. 8.950 .000 \\
\hline \multicolumn{3}{|l|}{ Ekuitas } \\
\hline Modal & Rp. 200.000 .000 & Rp. 200.000 .000 \\
\hline Prive & -Rp. 26.500 .000 & -Rp. 28.500 .000 \\
\hline Laba Ditahan & Rp. 310.000 .500 & Rp. 287.000 .600 \\
\hline Total Ekuitas & Rp. 483.500 & Rp. 458.500 .600 \\
\hline Total Keawjiban dan Ekuitas & Rp. 489.848 .395 & Rp. 467.450 .600 \\
\hline
\end{tabular}

Sumber: Data Diolah (2020)

\section{Tabel 3}

Persentase Biaya Kualitas Perusahaan Tahun 2019-2020

\begin{tabular}{lllll}
\hline \multicolumn{1}{c}{ Item } & \multicolumn{2}{c}{2019} & \multicolumn{1}{c}{ 2020 } \\
\cline { 2 - 5 } & \multicolumn{1}{c}{ Jumlah } & Persentase 2019 & \multicolumn{1}{c}{ Jumlah } & Persentase 2020 \\
\hline Biaya Penilaian & Rp. 41.800.000 & $5.8 \%$ & Rp. 47.400.000 & $16.3 \%$ \\
Biaya Pencegahan & Rp. 25.750 .000 & $3.6 \%$ & Rp. 30.900.000 & $10.6 \%$ \\
$\begin{array}{l}\text { Biaya Kegagalan } \\
\text { Internal }\end{array}$ & Rp. 5.300 .000 & $0.7 \%$ & Rp. 4.200.000 & $1.4 \%$ \\
$\begin{array}{l}\text { Biaya Kegagalan } \\
\text { Eksternal }\end{array}$ & Rp. 1.500 .000 & $0.2 \%$ & Rp. 1.068 .000 & $0.4 \%$ \\
Total Biaya Kualitas & Rp. 74.350.000 & $10.3 \%$ & Rp. 83.568.000 & $25.7 \%$ \\
\hline
\end{tabular}

Sumber: Data Diolah (2020)

Berdasarkan peringkat persentase biaya kualitas PT. Veloxa Viggo Inti Teknologi diatas, biaya kualitas yang banyak dikeluarkan terdapat pada biaya penilaian dan 
biaya pencegahan. Pada tahun 2019 biaya penilaian sebesar $5.8 \%$ dari penjualan senilai Rp 719,2 juta dan tahun 2020 biaya penilaian sebesar $16.3 \%$ dari penjualan senilai Rp 290,7 juta. Biaya kualitas penilaian mengalami peningkatan karena biaya gaji bagian packing dan controlling barang dagang yang terkadang membutuhkan jam diluar kerja/lembur. Biaya pencegahan pada tahun 2019 sebesar 3.6\% dari penjualan senilai Rp. 719,2 juta dan tahun 2020 biaya pencegahan sebesar 10.6\% dari penjualan senilai Rp. 290,7 juta. Biaya kualitas pencegahan juga meningkat pada biaya gaji trainner karena menurut pihak manajer apabila kualitas trainner yang baik maka produk jasa yang dihasilkan juga akan baik.

\section{Penerapan Biaya Kualitas $2.5 \%$ dari Penjualan}

Pada tahun 2019 dan tahun 2020 dapat diperoleh dari hasil rumus sebagai berikut:

a. Tahun 2019, dimana Total biaya kualitas $=2,5 \%$ dari Penjualan $=2,5 \% \mathrm{x}$ Rp. 719.246.890 = Rp. 17.981.172.

b. Tahun 2020 yang mana, Total biaya kualitas $=2,5 \%$ dari Penjualan $=2,5 \% \mathrm{x}$ Rp. $290.786 .567=$ Rp. 7.269.664.

Berdasarkan perhitungan penerapan biaya kualitas di atas dengan 2,5\% dari penjualan, bila PT. Veloxa Viggo Inti Teknologi melakukan investasi pada biaya penilaian dan biaya pencegahan maka perusahaan akan mengalami penurunan biaya kualitas sebesar Rp. 56.368 .827 (Rp. 74.350.000 - Rp. 17

981.172) untuk tahun 2019, pada tahun 2020 sebesar Rp. 76.298 .335 (Rp. 83.568.00 - Rp. 7.269.664).

\section{Laporan Laba/Rugi Penyesuaian}

Laporan Laba atau Rugi penyesuaian dapat dilihat pada Tabel 4.

\section{Tabel 4}

Laporan Laba/Rugi Penyesuaian Tahun 2019-2020

\begin{tabular}{|c|c|c|}
\hline & 2019 & 2020 \\
\hline Penjualan & Rp. 719.246.890 & Rp. 290.786 .567 \\
\hline Harga Pokok Penjualan & -Rp. 319.454.120 & -Rp. 83.454.120 \\
\hline Laba Kotor & Rp. 399.792 .770 & Rp. 207.332 .447 \\
\hline \multicolumn{3}{|l|}{ Beban Operasi } \\
\hline Biaya Karyawan Tetap \& Uang Muka & Rp. 84.897.689 & Rp. 36.789 .789 \\
\hline Biaya Pemasaran & Rp. 32.647 .900 & Rp. 16.641 .786 \\
\hline Biaya Penyusutan \& Amortisasi & Rp. 30.125 .000 & Rp. 15.688 .890 \\
\hline Biaya Perbaikan dan Pemeliharaan & Rp. 35.645 .000 & Rp. 17.889 .000 \\
\hline Biaya Utility, Adm. Sewa \& Lainnya & Rp. 5.600 .000 & Rp. 3.000 .000 \\
\hline \multirow[t]{2}{*}{ Biaya Kualitas } & Rp. 17.981 .172 & Rp. 7.269 .664 \\
\hline & 2019 & 2020 \\
\hline Jumlah Beban Operasi & Rp. 206.897.761 & Rp. 97.279.129 \\
\hline Laba Operasi & Rp. 192.895 .009 & Rp. 110.053 .318 \\
\hline \multicolumn{3}{|l|}{ Pendapatan Lain-lain } \\
\hline Pendapatan Bunga Deposito & Rp. 40.897 & Rp. 25.800 \\
\hline Pendapatan Lainnya & Rp. 120.602 .791 & Rp. 230.987 .675 \\
\hline Jumlah Pendapatan Lain-lain & Rp. 120.643 .688 & Rp. 231.013 .475 \\
\hline \multicolumn{3}{|l|}{ Beban Lain-lain } \\
\hline Biaya Bunga Pinjaman Lainnya & Rp. 897 & Rp. 789 \\
\hline Biaya Administrasi Bank \& buku Cek/Giro & Rp. 989.500 & Rp. 635.000 \\
\hline Biaya Pajak Jasa Giro/Tabungan & Rp. 1.897 & Rp. 1.678 \\
\hline Jumlah Beban Lain-lain & Rp. 992.294 & Rp. 637.467 \\
\hline Jumlah Pendapatan dan Beban Lain=lain & Rp. 119.651 .394 & Rp. 230.376 .008 \\
\hline Laba/Rugi Bersih (Before Tax) & Rp. 312.546 .403 & Rp. 340.429 .326 \\
\hline Pajak $1 \%$ & -Rp. 3.125 .464 & -Rp. 3.404.293 \\
\hline Laba/Rugi Bersih (After Tax) & Rp. 309.420 .939 & Rp. 337.025 .033 \\
\hline
\end{tabular}

Sumber: Data Diolah (2021) 
Tabel 5

Laporan EAT Perusahaan Tahun 2019-2020

\begin{tabular}{lll}
\hline & Tahun & EAT \\
\hline 2019 & Rp. 253.615.800 \\
2020 & Rp. 261.489.681 \\
\hline
\end{tabular}

Sumber: Data Diolah (2021)

\section{Laporan Tingkat Earning After Tax (EAT)}

Pada tabel 5 menunjukkan kenaikan yang terjadi pada tahun 2020 sebanyak Rp. 261.489.681 yang sebelumnya EAT ada 2019 hanya sebesar Rp. 253.615.800. Menurut pihak manajemen karena selama 2 tahun terahir permintaan pelanggan meningkat sehingga laba perusahaan juga meningkat

\section{Tingkat Profitabilitas PT. Veloxa Viggo Inti Teknologi}

Berikut ini adalah perhitungan rumus untuk tingkat Profitabilitas PT. Veloxa Inti Teknologi tahun 2019-2020 sebagai berikut:

GPM Tahun 2019: $\frac{\text { Rp.399.792.770 }}{\text { Rp.719.246.890 }} \times 100 \%=55.58 \%$

GPM Tahun 2020: $\frac{\text { Rp.207.332.447 }}{\operatorname{Rp} .290 .786 .567} \times 100 \%=71.30 \%$

Dari analisa perhitungan di atas menunjukan bahwa penjualan perusahaan pada tahun 2020 meningkat sebesar $71.30 \%$ dibandingkan tahun sebelumnya sebesar $55.58 \%$, karena permintaan konsumen meningkat sehingga profitabilitasnya semakin tinggi.

Profit On Sales tahun 2019 :

$\frac{\operatorname{Rp} 253.615 .800}{\operatorname{Rp} 719.246 .890} \times 100 \%=35.26 \%$

Profit On Sales tahun 2020 :

$\frac{\operatorname{Rp} 261.489 .681}{\operatorname{Rp} 290.786 .567} \times 100 \%=89.92 \%$

Berdasarkan hasil perhitungan di atas, untuk mengukur jumlah laba bersih setelah pajak pada penjualan bahwa pada tahun 2020 merupakan puncak penjualan paling tinggi sebesar $89.92 \%$. dibandingkan tahun 2019 sebesar $35.26 \%$.

ROE tahun 2019:



Berdasarkan analisis ROE bahwa pada tahun 2020 laba bersih yang dihasilkan perusahaan dengan ekuitas/modal sebesar 57.03\% dan tahun 2019 sebesar $52.45 \%$. Semakin tinggi penghasilan yang diperoleh maka semakin baik kedudukan pemilik perusahaan. 
Ekobis: Jurnal Ekonomi \& Bisnis

Vol. 2 No. 12021

ROA tahun 2019:

$\frac{\operatorname{Rp} 253.615 .800}{\operatorname{Rp} 647.396 .800} \times 100 \%=39.17 \%$

ROA tahun 2020:

$\frac{\operatorname{Rp} 253.615 .800}{\operatorname{Rp} 612.287 .360} \times 100 \%=42.71 \%$

Berdasarkan analisa diatas, menunjukan bahwa tahun 2020 dari total aktiva yang dipergunakan untuk operasi perusahaan mampu memberikan laba bagi perusahaan sebesar $42.71 \%$ dan pada tahun 2019 sebesar $39.17 \%$.

\section{Perbandingan Biaya Kualitas Dengan Tingkat Profitabilitas}

Pada Tabel 6 menunjukkan perbandingan antara total biaya kualitas PT. Veloxa Viggo Inti Teknologi dengan laba yang diukur dengan tingkat profitabilitas, dimana total biaya kualitas pada tahun 2019 sebanyak Rp. 74.350 .000 dengan tingkat profitabilitas GPM 55.58\%, Profit on sales $35.26 \%$, ROE 52.45\%, ROA $39.17 \%$. Sedangkan pada tahun 2020 total biaya kualitas tinggi sebesar Rp. 83.568.000 dengan tingkat profitabilitasnya juga meningkat GPM 71.30\%, Profit on sales $89.92 \%$, ROE $57.03 \%$, ROA $42.71 \%$.

\section{Hasil Analisis}

Pada PT. Veloxa Viggo Inti Teknologi biaya kualitas yang dikeluarkan berupa biaya pencegahan, biaya penilaian, biaya kegagalan internal dan biaya kegagalan eksternal. Biaya tersebut dilakukan analisa setiap objek yang berkaitan agar menjadi lebih rinci.

Dengan mengetahui biaya apa saja yang telah dikeluarkan oleh perusahaan, PT. Veloxa Viggo Inti Teknologi juga dapat menentukan tingkat kualitas produknya yang meliputi kinerja (performance), kehandalan (reliability), kesesuaian dengan spesifikasi (conformance to specifications), pelayanan (serviceability) dan persepsi kualitas (percived quality). Suatu produk dapat dikatakan memiliki kualitas yang baik jika terdapat tingkatan kualitas produk tersebut.

Setelah menentukan tingkatan kualitas produk, PT. Veloxa Viggo Inti Teknologi perlu menganalisis biaya kualitas yang berperan dalam meningkatkan profitabilitas perusahaan. Berdasarkan hasil analisis ada pengaruh signifikan antara biaya kualitas terhadap profit on sales. Hal ini dapat dibuktikan pada tahun 2019 total biaya kualitas sebesar 74,3 juta dan tingkat profitabilitas sebesar $35.26 \%$, sedangkan pada tahun 2020 total biaya kualitasnya tinggi sebesar 83,5 juta sehingga tingkat profitabilitasnya juga meningkat $89.92 \%$. Biaya kualitas yang tinggi dalam penelitian ini adalah biaya kualitas pada biaya penilaian dan pencegahan, dimana apabila kedua biaya tersebut meningkat maka banyak produk sesuai dengan spesifikasi dan semakin meningkatnya permintaan pelanggan sehingga membuat tingkat profitabilitas naik. 


\section{Tabel 6}

Perbandingan Biaya Kualitas dengan Profitabilitas 2019-2020

\begin{tabular}{cccccc}
\hline Tahun & $\begin{array}{c}\text { Total Biaya } \\
\text { Kualitas }\end{array}$ & GPM & $\begin{array}{c}\text { Profit } \\
\text { On Sales }\end{array}$ & ROE & ROA \\
\hline 2019 & Rp 74.350.000 & $55.58 \%$ & $35.26 \%$ & $52.45 \%$ & $39.17 \%$ \\
2020 & Rp 83.568 .000 & $71.30 \%$ & $89.92 \%$ & $57.03 \%$ & $42.71 \%$ \\
\hline
\end{tabular}

Sumber: Data Diolah (2021)

\section{SIMPULAN}

Berdasarkan hasil pembahasan dan analisa penelitian, maka kesimpulan yang dapat penulis jabarkan adalah sebagai berikut: (1) Sistem pencatatan biaya kualitas pada PT. Veloxa Viggo Inti Teknologi masih belum rinci. Hal ini dikarenakan bagian yang mencatat keuangan adalah staf administrasi yang merangkap banyak tugas dan latar belakang pendidikan tidak berasal dari akuntansi sehingga kualitas pencatatan laporan keuangan pun kurang stabil. Pencatatan seperti ini dapat menyebabkan perusahaan tidak mencatat keuangan perusahaan yang sebenarnya. (2) Perancangan laporan biaya kualitas PT. Veloxa Viggo Inti Teknologi terhadap profitabilitas mengalami peningkatan tahun 2019 sebesar $35.26 \%$ sedangkan tahun 2020 sebesar $89.92 \%$. Dari perancangan dan persentase tersebut dapat dikatakan bila perusahaan mengalokasikan biaya lebih banyak pada aktivitas pengendalian yaitu pada aktivitas pencegahan dan penilaian maka banyak produk yang sesuai dengan spesifikasi, sehingga permintaan pelanggan meningkat dan laba perusahaan dapat meningkat. (3) Pengkajian terhadap alur keuangan, uang masuk dan uang keluar dapat membuat keuangan tertata secara rapi dan dapat mengetahui secara jelas sehingga pengelolaan dana lebih terstuktur. Hal ini berguna untuk meningkatkan profitabilitas keuangan, menghindari adanya fraud dan dampak kesalahan laporan dalam jangka panjang yang berdampak buruk pada usia dan juga kesehatan perusahaan.

\section{DAFTAR PUSTAKA}

Atkinson, A. A. (2012). Akuntansi Manajemen. Jakarta: PT. Indeks.

Blocher, J. E. (2007). Cost Management: Manajemen Biaya Penekanan. Jakarta: Salemba Empat.

Blocher, J. E., Chen, K. H., \& Lin, T. W. (2000). Manajemen Biaya Buku I. Jakarta: Salemba Empat.

Dewi, R. P. (2019). Penyusunan Laporan Kualitas pada PT. Temprina Media Grafika. Surabaya: Universitas Katolik Widya Mandala.

Gaspersz, V. (2012). Total Quality Management. Jakarta: PT. Gramedia Pustaka.

Gazpersz, V. (2012). All-In-One Management Tool Book. Jakarta: Tri Al Bros Publishing.

Hansen, \& Mowen. (2005). Management Accounting Buku 2 Edisi ke 7. Jakarta: Salemba Empat. 
Hansen, \& Mowen. (2009). Akuntansi Manajerial. Jakarta: Salemba Empat.

Harahap, S. S. (2016). Analisis Laporan Keuangan. Depok: PT. Rajagrafindo Persada.

Hardiansyah, H. (2012). Metodologi Penelitian Kualitatif Untuk Ilmu- Ilmu Sosial. Jakarta: Salemba Humanika.

Hariadi, B. (2011). Akuntansi Manajemen Suatu Sudut Pandang. Yogyakarta: BPFEYogyakarta.

I, N., \& S, B. (2008). Metodologi Penelitian Bisnis Untuk Akuntansi dan Manajemen. Yogyakarta: BPFE.

Ishak, A., \& Luthfi, Z. (2011). Pengaruh Kepuasan Dan Kepercayaan Konsumen terhadap Loyalitas: Studi tentang peran mediasi switching costs. Jurnal siasat bisnis 15.1, 11-19.

Lin, T. W., Chen, K. H., \& Blocher, J. E. (2002). Manajemen Biaya. Jakarta: Salemba Empat.

Narbuko, C., \& Achmadi, A. (2006). Metodologi Penelitian. Jakarta: Bumi Aksara.

Noor, J. (2012). Metodologi Penelitian. Jakarta: Kencana.

Prawirosentono, S. (2009). Filosofi Baru Tentang Manajemen Mutu Terpadu. Jakarta: PT. Bumi Aksara.

Purwanti, A. (2013). Akuntansi Manajemen. Jakarta: Mitra Wacana Media.

Ratag, N. D., Saerang, D. E., \& Mawikere, L. (2016). Penerapan Biaya Kualitas Dalam Meningkatkan Efisiensi Produksi Pada PT. Tropica Cocoprima. Manado: Universitas Sam Ratulangi.

Rizka, I. J. (2019). Peranan Biaya Kualitas dalam Mendukung Pengendalian Kualitas Produk pada UD. Mutiara Rasa Jember. Jember: Universitas Muhammadiyah.

Russel, R. S., Taylor III, \& B. W. (2014). Operations and Supply Chain Management. Singapore: John Wiley \& Sons.

Siregar, B., Suripto, B., Hapsoro, D., Lo, E. $\quad$ W., $\quad$ \& $\quad$ Biyanto, $\quad$ F. $\quad$ (2013). Akuntansi Manajemen. Jakarta: Salemba Empat.

Sugiono. (2010). Memahami Penelitian Kualitatif. Bandung: Alfabeta.

Sugiono. (2017). Metode Penelitian Kuantitatif, Kualitattif, R\&D. Bandung: Alfabeta.

Supriyono. (2010). Akuntansi Biaya pengumpulan biaya dan penentuan harga pokok. Yogyakarta: BPFE- Yogyakarta. 
Ekobis: Jurnal Ekonomi \& Bisnis

Vol. 2 No. 12021

Lia Anatasya dkk., Analisis Penerapan Biaya Kualitas

Sutrisno. (2016). Metode Research II. Yogyakarta: Unversitas Gajah Mada.

Sutrisno, E. (2014). Manajemen Sumber Daya Manusia. Jakarta: Pranada Media Group.

Widyaningdyah, A. U. (2013). Intellectual Capital dan Keunggulan Kompetitif (Studi Empiris Perusahaan Manufaktur versi Jakarta Stock Industrial ClassificationJASICA). Jurnal Akuntansi dan Keuangan 15.1, 2-14. 